Paweł Magiera

Uniwersytet Papieski Jana Pawła II w Krakowie

\title{
Spór o zawarcie konkordatu ze Stolicą Apostolską w debacie konstytucyjnej Sejmu Ustawodawczego z lat 1919-1921
}

\section{Wprowadzenie}

Kwestia zawarcia przez odrodzone w 1918 r. państwo polskie konkordatu ze Stolicą Apostolską, zwieńczona ratyfikacją tej umowy przez sejm w 1925 r., doczekała się dotąd bardzo obszernej literatury przedmiotu, której całościowe zestawienie może sprawić badaczowi spore trudności. Niemniej jednak podkreślić należy, iż opracowania dotychczasowe, podejmujące kwestię konkordatu z 1925 r., skupiały się zwykle na analizie okresu następującego już po uchwaleniu konstytucji z 17 marca 1921 r., w której explicite znalazła się zapowiedź zawarcia tego rodzaju umowy międzynarodowej (art. 114) ${ }^{2}$. W związku z tym w istniejącym piśmiennictwie naukowym dostatecznie dobrze omówione są zwłaszcza takie aspekty, jak: tworzenie kolejnych wersji projektu konkordatu z inspiracji Ministerstwa Wyznań Religijnych i Oświecenia Publicznego, negocjacje ze Stolicą Apostolską prowadzone przez Stanisława Grabskiego, czy wreszcie debata sejmowa nad ratyfikacją

Artykuł stanowi zmodyfikowany fragment III rozdziału pracy magisterskiej obronionej przez autora we wrześniu 2017 r. w Instytucie Historii Uniwersytetu Jagiellońskiego w Krakowie. Praca pt. Debata w Sejmie Ustawodawczym (1919-1922) nad publicznoprawna i polityczna pozycja Kościoła katolickiego w Polsce została przygotowana pod kierunkiem prof. Czesława Brzozy. Obecnie autor jest doktorantem na Wydziale Historii i Dziedzictwa Kulturowego Uniwersytetu Papieskiego Jana Pawła II w Krakowie.

2 Ustawa z dnia 17 marca 1921 r. Konstytucja Rzeczypospolitej Polskiej, Dz.U. RP z 1921 r., nr 44, poz. 267. 
konkordatu z 1925 r. Brakuje jednak dotąd szerszego i całościowego omówienia pierwszej debaty parlamentarnej nad kwestią konkordatu, która toczyła się w latach 1919-1921 w Sejmie Ustawodawczym w ramach prac nad przepisami wyznaniowymi przyszłej konstytucji. Miała ona odpowiedzieć na pytanie o zasadność i potrzebę zawarcia konkordatu, a przez to przesądzić, czy zapowiedź przeprowadzenia rokowań w tej sprawie znajdzie się w ustawie zasadniczej odrodzonej Polski.

Niniejszy artykuł stanowi próbę omówienia tej swoistej debaty „na przedpolu" prac konkordatowych, celem wypełnienia, przynajmniej w pewnym stopniu, istniejącej w tym zakresie luki badawczej. Prezentowane zagadnienie przedstawione zostanie w ujęciu chronologicznym, z zachowaniem zasadniczego porządku prac konstytucyjnych, co pozwoli osiągnąć należytą klarowność wywodu. Przy odtwarzaniu przedstawionej w artykule dyskusji nad problemem konkordatu, toczącej się w konstytuancie, oparto się przede wszystkim na istotnych źródłach, tj. sprawozdań stenograficznych z posiedzeń Sejmu Ustawodawczego (oficjalny, urzędowy zapis przebiegu posiedzeń ówczesnego parlamentu) oraz na drukach tego sejmu, zawierających zwłaszcza projekty legislacyjne, w tym także projekty konstytucji, które wpłynęły drogą formalną do izby bądź zostały opracowane przez sejmową Komisję Konstytucyjną ${ }^{4}$.

Należy podkreślić, iż debata Sejmu Ustawodawczego z lat 1919-1921 nad problemem zawarcia przez Polskę konkordatu ze Stolicą Apostolską, regulującego szczegółowe zagadnienia z zakresu stosunków Kościoła i państwa, znacząco wyprzedziła realne działania dyplomatyczne podjęte w celu przygotowania tej umowy ${ }^{5}$. W związku z tym prowadzona w konstytuancie

Cząstkowe informacje dotyczące pierwszej parlamentarnej debaty nad zasadą konkordatu w Sejmie Ustawodawczym rozsiane są w ramach szerszych tematycznie opracowań dotyczących zwłaszcza prac nad Konstytucją marcową. Koronnym przykładem takiej literatury jest: S. Krukowski, Geneza konstytucji z 17 marca 1921 r., Warszawa 1977.

$4 \quad$ Na potrzeby artykułu korzystano z tych materiałów w wersji udostępnionej online na stronie internetowej Biblioteki Sejmowej, w bazie danych o nazwie „Parlamentaria polskie 1919-1997". Występuje ona pod adresem: https://bs.sejm.gov. $\mathrm{pl} / \mathrm{F} /$ ? func $=$ file\&file_name $=$ find-nowe\&local_base $=\operatorname{ars01}(25.08 .2018)$.

$5 \quad$ Wobec żywych wątpliwości episkopatu Polski co do zasadności zawarcia konkordatu (a zwłaszcza przekonania o tym, iż jest to postulat co najmniej przedwczesny i należy wstrzymać się z nim aż do momentu przyjęcia konstytucji) pierwsze wysiłki dyplomatyczne w sprawie zawarcia układu ze Stolicą Apostolską podjęto dopiero po uchwaleniu konstytucji, w kwietniu 1921 r., gdy rząd przesłał na ręce nuncjusza apostolskiego w Polsce notę dyplomatyczną, zawierającą deklarację 
dyskusja sprowadzała się wyłącznie do wstępnej oceny samej zasadności zawarcia konkordatu traktowanego jako jedna z możliwych do wyboru form prawnych szczegółowego ułożenia relacji między Kościołem katolickim a państwem polskim. Problem ten był poruszany w ramach sejmowej debaty konstytucyjnej, gdyż to właśnie w treści przepisów wyznaniowych przyszłej konstytucji miała zostać przesądzona konkretna forma prawna dookreślenia wzajemnych stosunków. W ustawie zasadniczej mogły się zatem znaleźć zasadniczo dwa różne rozwiązania. Pierwszym była zapowiedź zawarcia umowy międzynarodowej ze Stolicą Apostolską (konkordat - jak chciała tego prawica) wiążąca się zwykle z przyjęciem odmiennych rozwiązań formalnych wobec pozostałych związków wyznaniowych. Drugie rozwiązanie stanowiła z kolei regulacja umożliwiająca jednostronne i władcze, znormalizowane co do formy prawnej, kształtowanie przez państwo swych stosunków ze wszystkimi związkami wyznaniowymi, w tym także z Kościołem katolickim (np. poprzez wydanie stosownego aktu prawnego o randze ustawowej - jak proponowała zwykle przeciwna konkordatowi lewica). Co istotne, zabrakło w toku debaty parlamentarnej z lat 1919-1921 rozważań na temat merytorycznego kształtu takiego porozumienia ze Stolicą Apostolską, gdyż decydowała się wówczas tylko sama "zasada konkordatu" wraz z kwestią jej konstytucyjnego umocowania.

2. Pierwsze poglądy na temat konkordatu wyrażone w toku początkowych prac ustrojowych Sejmu Ustawodawczego (1. połowa 1919 r.)

Pierwszy głos na poruszony wyżej temat wybrzmiał w parlamencie już w lutym 1919 r. w ramach prezentacji oświadczeń programowych poszczególnych klubów poselskich, towarzyszącej wystąpieniu premiera Ignacego Paderewskiego. Wtedy też Ignacy Daszyński, ze zrzeszającego sejmowych socjalistów Związku Polskich Posłów Socjalistycznych ${ }^{6}$ (ZPPS), postulował

woli wszczęcia negocjacji w tej sprawie. O przebiegu prac nad konkordatem zob. szerzej: J. Wisłocki, Konkordat polski z 1925 roku. Zagadnienia prawno-polityczne, Poznań 1977, s. 70-92; K. Krasowski, Konkordat polski z 1925 roku. Geneza - postanowienia-wykonanie, "Czasopismo Prawno-Historyczne", t. 59, nr 2 (2007), s. 109128; J. Dębiński, O konkordacie polskim z 1925 roku, "Saeculum Christianum", t. 14, nr 1 (2007), s. 169-176; W. Wójcik, Konkordat polski z 1925 roku. Próba oceny, w: Kościół w II Rzeczypospolitej, red. Z. Zieliński, S. Wilk, Lublin 1980, s. 17-21.

6 Przy określaniu bieżącej przynależności klubowej poszczególnych posłów korzystano z szeregu źródeł oraz opracowań. Wśród nich wymienić należy zwłaszcza druki sejmowe prezentujące oficjalne składy personalne izby na dzień 12 IV 1919 r.

Paweł Magiera, Spór o zawarcie konkordatu ze Stolica Apostolską... 
w imieniu swego klubu, aby wzajemne relacje państwa i wszystkich wyznań były regulowane w jednakowej formie ustawowej ${ }^{7}$, a więc na drodze jednostronnego aktu prawnego uchwalanego przez władzę państwową (jej najwyższy organ ustawodawczy). Wnioskując a contrario z przedstawionego stanowiska, można zatem stwierdzić, że I. Daszyński wykluczał tym samym możliwość zawarcia konkordatu ze Stolicą Apostolską.

Pretekstem do szerszej dyskusji okazały się jednak dopiero propozycje zawarte w przedłożonych sejmowi w początkach maja 1919 r. projektach konstytucji zgłoszonych przez rząd I. Paderewskiego i klub PSL "Wyzwolenie". W rządowym „projekcie deklaracji konstytucyjnej" wprowadzono dwojaki system ustalania stosunków szczegółowych między państwem a związkami wyznaniowymi. W przypadku Kościoła katolickiego zapowiadano wydanie ustaw o treści opracowanej na podstawie dwustronnego porozumienia ze Stolicą Apostolską, natomiast w odniesieniu do pozostałych wyznań decydować miało jednostronnie państwo po wysłuchaniu uchwał opiniujących podjętych przez reprezentację danego wyznania (rozdział XII) ${ }^{8}$. Z kolei w projekcie „Wyzwolenia” (wydanego pod nazwą "Podstawa ładu Rzeczypospolitej Polskiej") nie wprowadzano takiego zróżnicowania i ustanowiono dotyczącą wszystkich wyznań (również katolicyzmu) zapowiedź ustalenia wzajemnego stosunku prawnego z państwem na drodze jednolitych bilateralnych umów (tytuł XII) ${ }^{9}$.

Podczas pierwszej debaty konstytucyjnej z maja 1919 r. kwestia ewentualnego zawarcia konkordatu została szerzej poruszona przez I. Daszyńskiego (ZPPS). Komentując regulacje rządowego "projektu deklaracji konstytucyjnej", zdecydowanie sprzeciwiał się on zapowiedzi porozumienia ze Stolicą Apostolską, uznając ją za rozwiązanie przestarzałe. Uważał, że każda konstytucja winna wprowadzać nowe rozwiązania ustrojowe, kształtować

(druk nienumerowany) oraz 21 I 1920 r. (druk nr 1551), jak również ówczesne podręczniki wyborcze (T. Rzepecki, Sejm Rzeczypospolitej Polskiej 1919 roku, Poznań 1920) i szczególnie cenne naukowo monografie (S. Krukowski, Geneza konstytucji..., op. cit.). Podkreślić należy, że dla okresu prac Sejmu Ustawodawczego brakuje pełnych danych źródłowych, umożliwiających całkowite i precyzyjne odtworzenie migracji międzyklubowych. Dotyczy to jednak głównie lat 1921-1922, tj. okresu po uchwaleniu konstytucji, który nie jest przedmiotem niniejszego opracowania.

7 Sprawozdanie stenograficzne z 4 posiedzenia Sejmu Ustawodawczego z 22 II 1919 r., łam 137 [dalej zapis skrócony wedle wzoru: Spr. sten. SU, 4 pos. z 22 II 1919 r., ł. 137].

8 Projekt deklaracji konstytucyjnej, druk Sejmu Ustawodawczego [dalej: SU] nr 443a, s. 8.

$9 \quad$ Podstawa ładu Rzeczypospolitej Polskiej, druk SU nr 443, s. 8. 
nowy ład. Natomiast konkordat był w jego przekonaniu instrumentem wychodzącym powoli z użycia. Socjalista podkreślał, że żadne inne państwo katolickie, nawet tak jednolite religijnie jak Włochy, nie planowało zawarcia konkordatu. Dlatego też tym bardziej nie powinna tego robić Polska, w której granicach zamieszkiwali obywatele różnych narodowości i wyznań. Poza tym Daszyński twierdził, że zawarcie konkordatu doprowadzi do odstąpienia Stolicy Apostolskiej części suwerennych uprawnień sejmu w sprawach kulturalnych i religijnych, gdyż na stosowne regulacje wzajemnych stosunków Kościoła i państwa w tych sferach zgodzić się będzie musiał także papież $\dot{z}^{10}$.

Krytyczne stanowisko w omawianej kwestii zajął też Władysław Kiernik z PSL „Piast". Piętnując niekonsekwencję ideową projektu rządowego, uznał on między innymi zapowiedź konkordatu za należącą do "najdalej idących postulatów katolickich". Akcentował w ten sposób nadmiernie konserwatywny - jego zdaniem - charakter tego rozwiązania ${ }^{11}$.

W kwestii konkordatu wypowiedział się wówczas również abp Józef Teodorowicz ze Związku Sejmowego Ludowo-Narodowego (ZSLN), czyli klubu-federacji stronnictw prawicy, któremu przewodziła endecja. Mówca ten podkreślał, że o sensie zawierania konkordatu rozmawiać można dopiero, kiedy pozna się z grubsza jego przyszłe postanowienia. Możliwe było bowiem także opracowanie konkordatu na warunkach zgoła niekorzystnych dla Kościoła, a wtedy zdaniem arcybiskupa lepiej by było katolikom polskim obyć się bez tego aktu, tak jak to miało miejsce na przykład we Francji12. Dość zdystansowana postawa, jaką wobec sprawy konkordatu zajął ormiański arcybiskup, wynikała z jego prywatnych obaw związanych z potencjalnym ograniczeniem w drodze takiej umowy zakresu autonomii wewnętrznej Kościoła. J. Teodorowicz uchodził w episkopacie Polski za jednego z liderów duchowieństwa ostrożnego wobec koncepcji zawarcia konkordatu, dawał temu wyraz zwłaszcza po uchwaleniu konstytucji i w okresie rokowań konkordatowych ${ }^{13}$.

10 Spr. sten. SU, 36 pos. z 10 V 1919 r., ł. 17-18, 26. Por. S. Michałowski, Religia i Kościół rzymskokatolicki w myśli politycznej Polskiej Partii Socjalistycznej 1918-1939, w: Religia i Kościół rzymskokatolicki w polskiej myśli politycznej 1919-1993, red. J. Jachymek, Lublin 1995, s. 141.

11 Spr. sten. SU, 37 pos. z 13 V 1919 r., ł. 28.

12 Spr. sten. SU, 36 pos. z 10 V 1919 r., ł. 41.

13 K. Krasowski, Między Warszawa a Watykanem. Episkopat Polski wobec rzadu i Stolicy Apostolskiej 1918-1939, w: Szkice z dziejów papiestwa, t. 1, red. I. Koberdowa, 
Regulacje projektu rządowego dotyczące form ustalenia stosunków między państwem a związkami wyznaniowymi ocenili też w trakcie pierwszej sejmowej debaty konstytucyjnej posłowie żydowscy. Zarówno Izaak Grünbaum (syjonista), jak i Samuel Hirszhorn (fołkista) zwracali uwagę na obiektywne trudności wiążące się z powołaniem reprezentacji wyznania mojżeszowego (np. brak sformalizowanej hierarchii kościelnej), która według projektu miała wyrazić swą opinię na temat ułożenia stosunków tego wyznania z państwem. Obaj podkreślali, że reprezentacja taka musiałaby występować w imieniu całej społeczności żydowskiej w Polsce, a co za tym idzie, winna zostać wyłoniona w sposób demokratyczny ${ }^{14}$.

Odmienne postanowienia w kwestii prawnej formy określania szczegółowych stosunków państwa i wyznań zawierały trzy projekty poselskie zgłoszone w sejmie u schyłku maja 1919 r. Zgodnie z art. 19 projektu ZPPS o pozycji prawnej wyznań decydować miało jednostronnie państwo w drodze ustawy o stowarzyszeniach. Nie przewidywano więc ani oddzielnych porozumień ze związkami wyznaniowymi, ani odrębnych ustaw, poprzedzonych konsultacjami z reprezentacją danego wyznania, a traktowano je na równi z wszelkimi innymi typami stowarzyszeń, których pozycję regulować miał wspólny, ogólny akt ustawowy, którego wydanie zapowiedziano wprost w proponowanym artykule ${ }^{15}$. W projekcie prof. Józefa Buzka, wzorowanym na ustroju amerykańskim i wniesionym do sejmu za grzecznościowym poparciem pojedynczych posłów różnych klubów, także nie przewidziano zawarcia konkordatu, a jedyną regulacją w tej sprawie był lakoniczny art. 28, który stanowił, że "ustawodawstwo o stosunku państwa do Kościoła i do stowarzyszeń religijnych przysługuje sejmowi narodowemu"16. Oznaczało to zapowiedź regulowania wzajemnych stosunków w drodze jednostronnych aktów państwowych (ustaw) uchwalanych przez parlament federalny (projekt wprowadzał ustrój federacyjny). Tylko projekt endeckiego Związku Ludowo-Narodowego (ZLN), przygotowany przez prof. Stanisława Głąbińskiego, zapowiadał określenie stosunku państwa do Kościoła rzymskokatolickiego w drodze dwustronnego porozumienia ze Stolicą Apostolską (konkordat). W stosunku do innych wyznań

J. Tazbir, Warszawa 1989, s. 298. Por. S. Wilk, Episkopat Kościoła katolickiego w Polsce w latach 1918-1939, Warszawa 1992, s. 98.

14 Spr. sten. SU, 37 pos. z 13 V 1919 r., $1.9-10,67-68$.

15 Tymczasowa Ustawa Konstytucyjna Rzeczypospolitej Polskiej, druk SU nr 443c, s. 4.

16 Projekt Konstytucji Rzeczypospolitej Polskiej, druk SU nr 443e, s. 12. 
miało się to odbywać jednostronnie na podstawie ustaw uchwalanych po wysłuchaniu niewiążących wniosków przedstawionych przez ich reprezentacje (art. 19) $)^{17}$.

3. Kwestia zawarcia konkordatu podczas zasadniczych prac sejmowej Komisji Konstytucyjnej i II plenarnego czytania projektu konstytucji

W sytuacji podjęcia w drugiej połowie 1919 r. równoległych prac nad konstytucją przez sejmową Komisję Konstytucyjną i rząd I. Paderewskiego rozwiązania przyjęte w projektach obu ośrodków odnośnie do form szczegółowej regulacji stosunków państwa ze związkami wyznaniowymi wykazywały daleko idącą zbieżność. Wynikało to z wyboru wspólnego źródła inspiracji, jakim dla obu projektów był projekt ZLN. Jego autor, wspomniany już poseł endecji S. Głąbiński, był jednocześnie referentem zagadnień wyznaniowych na posiedzeniach Komisji. Z uwagi na powyższe w obu projektach znalazł się właściwie tożsamy, dwoisty system, w myśl którego stosunek państwa do Kościoła rzymskokatolickiego miał być prawnie określony na podstawie porozumienia ze Stolicą Apostolska, a stosunki z pozostałymi wyznaniami ustalone jednostronnie przez stronę państwową "po wysłuchaniu wniosków ich reprezentacji". Jednocześnie w projekcie komisyjnym, zgodnie ze wzorcem z projektu ZLN, podkreślono, iż regulacja stosunków z innymi wyznaniami będzie miała formę ustawy (art. 23) ${ }^{18}$, podczas gdy projekt rządowy formy tej nie precyzował (art. 87) ${ }^{19}$. W toku dalszych prac ustrojowych Komisji Konstytucyjnej pozostawiono wspomniane regulacje bez zmian merytorycznych. Przed ostatnim komisyjnym czytaniem dokonano tylko drobnej modyfikacji redakcyjnej polegającej na wydzieleniu do osobnego artykułu zapisu o sposobie ustalania stosunku państwa do innych wyznań ${ }^{20}$. W rezultacie w ostatecznej wersji projektu, przedstawionej sejmowi do II plenarnego czytania w czerwcu 1920 r., omawianą problematykę zawarto w art. 117 ust. 2 zd. 2 (konkordat) oraz w art. 118 (jednostronna regulacja stosunków z innymi wyznaniami na drodze ustawowej, poprzedzona

$17 \quad$ Projekt Konstytucji Rzeczypospolitej Polskiej, druk SU nr 443d, s. 5.

18 Tekst projektu ustawy konstytucyjnej Rzeczypospolitej Polskiej uchwalony w drugim czytaniu przez Komisję Konstytucyjna Sejmu Ustawodawczego, druk SU nr 1534, s. 9.

19 Ustawa Konstytucyjna Rzeczypospolitej Polskiej, druk SU nr 443f, s. 12.

20 Zob. Tekst projektu ustawy konstytucyjnej Rzeczypospolitej Polskiej przygotowany do ostatniego czytania przez Komisję Konstytucyjna Sejmu Ustawodawczego, druk SU nr 1781, s. 28.

Paweł Magiera, Spór o zawarcie konkordatu ze Stolica Apostolska... 
wysłuchaniem niewiążących wniosków ich reprezentacji). Warto dodać, że socjaliści z ZPPS zgłosili poprawkę zakładającą skreślenie obu artykułów (i regulację statusu związków wyznaniowych na równi z innymi zrzeszeniami w ustawie o stowarzyszeniach). Natomiast Wolny Związek Posłów Narodowości Żydowskiej (zwany popularnie Kołem Żydowskim) przedstawił poprawkę do art. 118 polegającą na dodaniu nowego ustępu, precyzującego, iż reprezentacja wyznaniowa musiała być wyłoniona "na zasadzie obowiązujących w odnośnym wyznaniu przepisów lub też w drodze wyborów, na ogólnych zasadach przeprowadzonych"21.

Przeprowadzona w ramach II czytania projektu konstytucji dyskusja nad ustaleniem prawnych form regulowania szczegółowych stosunków między państwem a związkami wyznaniowymi toczyła się zarówno podczas ogólnej debaty nad całym rozdziałem V projektu Komisji Konstytucyjnej, jak i przy okazji szczegółowego omawiania art. 117 (zapowiedź zawarcia konkordatu ze Stolicą Apostolską) oraz art. 118 (ustawowy tryb regulowania stosunków z pozostałymi wyznaniami) tegoż projektu. W trakcie debaty nad tymi problemami pojawiły się w sejmie dwa odmienne stanowiska z jednej strony wyrażano aprobatę dla rozwiązań przyjętych przez Komisję, a z drugiej poddano je wyraźnej krytyce. Polaryzacja postaw dotyczyła szczególnie sprawy konkordatu, na której w większym stopniu skupiła się uwaga posłów.

Krytyczne stanowisko wobec idei zawarcia konkordatu zajęła oczywiście sejmowa lewica. Pierwszy wypowiadał się w tej kwestii Kazimierz Czapiński z ZPPS. Przekonywał, że nawet nie wszyscy duchowni popierali postulat podpisania konkordatu, a wręcz przeciwnie, byli i tacy którzy uważali, iż będzie on stanowić dla Kościoła w Polsce privilegium odiosum ${ }^{22}$, "za który organizacja kościoła później tylko pokutować może". Socjalista przewidywał, że sformułowany przez większość Komisji Konstytucyjnej postulat konkordatu może zostać przyjęty w przyszłej konstytucji, dlatego też apelował do izby, aby oparła się w tym przypadku na wzorcu konkordatu

$21 \quad$ Konstytucja Rzeczypospolitej Polskiej, w: Sprawozdanie Komisji Konstytucyjnej o Konstytucji Rzeczypospolitej Polskiej, druk SU nr 1883, s. 44.

22 Z języka łacińskiego dosłownie „przywilej niekorzystny" lub „przywilej szkodliwy". Obszernym rozważaniom na temat właściwego rozumienia i tłumaczenia tego zwrotu poświęcono artykuł, zob. M. Dyjakowska, Privilegium odiosum. O znaczeniu kontekstu w przekładzie terminologii prawniczej, "Roczniki Humanistyczne", t. 61 , $\mathrm{nr} 8$ (2013), s. 149-161. 
francuskiego z 1802 r., który był korzystny dla państwa, szczególnie w kwestii zrzeczenia się przez kler francuski dóbr pokościelnych odebranych Kościołowi przez władze rewolucyjne. Socjalistyczny poseł podobne działania sugerował duchowieństwu polskiemu i sejmowej prawicy, skoro tak chętnie powoływali się oni na przykład Francji, choćby w sprawie senatu ${ }^{23}$.

Z kolei Józef Putek z PSL-Lewicy starał się podkreślić niekorzystne strony ewentualnego zawarcia konkordatu. Uznał on tę instytucję za taktyczny wybieg w podstępnej i imperialistycznej polityce kurii rzymskiej, która w jego przekonaniu zawsze dążyła do ostatecznego celu, jakim było podporządkowanie państw świeckich swoim widokom politycznym. Podkreślał, że „Rzym każdy konkordat traktował nie jako akt dobrej woli, nie jako ugodę dwóch stron, lecz jako akt narzucony i zawsze szukał sposobności, aby się wyzwolić z pod postanowień konkordatu. Wszystkim usiłuje on narzucić prawo kanoniczne jako bezwzględnie obowiązujące, a każdy wyłom uczyniony w tym przez konkordat traktuje jako objaw przejściowy"24. Ponadto zdaniem J. Putka zawarcie konkordatu i tak nie dałoby żadnych korzyści politycznych, czego dobitnie dowodził dotychczasowy bilans stosunków ze Stolicą Apostolską, szczególnie w kwestii plebiscytów na Warmii i Mazurach oraz na Górnym Śląsku, gdzie rzekome próby załagodzenia antypolskiej agitacji księży niemieckich przez mianowanego wysokim komisarzem dla spraw kościelnych na tereny plebiscytowe nuncjusza Achillesa Rattiego okazały się nieskuteczne i dowiodły braku wpływu kurii rzymskiej na tamtejszy kler²5. W dodatku poseł Lewicy PSL zaznaczał, że mimo braku konkordatu utworzono kosztowne poselstwo polskie w Watykanie, które w przekonaniu mówcy nie przynosiło żadnych realnych korzyści dyplomatycznych $^{26}$.

Sceptycznie do komisyjnego ujęcia kwestii konkordatu odniósł się w imieniu klubu PSL „Wyzwolenie” jeden z jego liderów, Andrzej Waleron. Zwracał on uwagę, że w art. 117 nie doprecyzowano zakresu i rodzaju spraw, które miały zostać uregulowane na drodze porozumienia ze Stolicą Apostolską. W związku z tym poseł „Wyzwolenia" obawiał się, że z uwagi

23 Spr. sten. SU, 180 pos. z 29 X 1920 r., ł. 25, 27-28.

24 Spr. sten. SU, 181 pos. z 4 XI 1920 r., ł. 27.

25 Por. H.E. Wyczawski, Kościół w odrodzonym państwie polskim (1918-1939), w: Historia Kościoła w Polsce, t. II, cz. 2, red. B. Kumor, Z. Obertyński, Poznań-Warszawa 1979, s. 24 . Spr. sten. SU, 181 pos. z 4 XI 1920 r., ł. 28-29.

Paweł Magiera, Spór o zawarcie konkordatu ze Stolica Apostolska... 
na deklarowaną zasadę autonomii kościelnej będą to w większości sprawy doczesne, związane zwłaszcza z władaniem dobrami ziemskimi. Zdaniem mówcy kwestie te mogły być regulowane wyłącznie suwerennymi decyzjami władz państwowych, nie powinny być zatem przedmiotem umów z podmiotami zewnętrznymi. Również ogólnie rozumiana kwestia stosunku państwa do Kościoła, stanowiącego przecież wspólnotę wiernych (a więc obywateli polskich), była zdaniem A. Walerona wewnętrzną sprawą Rzeczypospolitej. W takim układzie postulat zawarcia konkordatu oznaczał „ingerencję czynników postronnych" i naruszał zasadę suwerenności państwa polskiego wyrażoną w art. 2 projektu. Zmierzając do konkluzji swej wypowiedzi, poseł ten uznał, że art. 117 zawiera przywilej dla Kościoła katolickiego, a dokładniej dla stanu duchownego ${ }^{27}$.

Na uprzywilejowaną pozycję Kościoła katolickiego zwracali uwagę również posłowie zabierający głos podczas rozprawy nad art. 118 projektu konstytucji. Zarówno fołkista S. Hirszhorn, jak i J. Putek (PSL-Lewica) podkreślali nierówność w traktowaniu Kościoła katolickiego i innych wyznań w zakresie formy ustalania szczegółowych stosunków z państwem. Porównując artykuły 117 i 118, obaj parlamentarzyści wskazywali bowiem, że relacja z Kościołem katolickim ma być określana w drodze dwustronnego porozumienia, natomiast stosunek do pozostałych wyznań będzie regulowany przez państwo jednostronnie. Choć władze państwowe musiały zapoznać się uprzednio ze stanowiskiem reprezentacji danego wyznania, to jednak nie były one w żaden sposób tymi opiniami związane i mogły je swobodnie zignorować ${ }^{28}$. W takim ujęciu konkordat traktowany był jako przywilej dla Kościoła katolickiego, naruszający zdaniem mówców zasadę równości wobec prawa. Ponadto poseł Hirszhorn podkreślał obiektywne trudności wiążące się z wyłonieniem reprezentacji wyznania żydowskiego, powołanej w myśl projektu do konsultacji z państwem. Obawiał się, że brak precyzji na gruncie art. 118 odnośnie do sposobu wybierania takiej reprezentacji może prowadzić do różnych nadużyć ze strony państwa, w tym do narzucenia wierzącym Żydom jedynie fasadowego przedstawicielstwa. Podkreślał więc konieczność wyłonienia takiej reprezentacji w sposób demokratyczny spośród wybranych przez ogół rabinów ${ }^{29}$. 2004, s. $80-81$. 
Za rozwiązaniami proponowanymi przez Komisję Konstytucyjną opowiedział się z kolei Alfred Halban z konserwatywnego Klubu Pracy Konstytucyjnej (KPK). W swoim bardzo rzeczowym przemówieniu, trzymającym się ściśle meritum poruszanych w debacie kwestii ustrojowych, stanowczo sprzeciwił się traktowaniu zapowiedzi konkordatu w kategoriach specjalnego przywileju dla Kościoła katolickiego. Podkreślał, że przyjęta w art. 117-118 odmienna forma regulowania przez państwo stosunków wzajemnych z tym Kościołem i z resztą wyznań była wyłącznie bezpośrednią konsekwencja jego wyjątkowej, hierarchicznej struktury organizacyjnej. Tylko w przypadku Kościoła katolickiego istniała bowiem scentralizowana, zwierzchnia i ponadnarodowa władza kościelna (Stolica Apostolska), będąca suwerennym podmiotem prawa międzynarodowego, posiadającym wyłączną w Kościele kompetencję do zawierania takich umów. Nie można było więc uregulować pozycji religii katolickiej w państwie w drodze choćby porozumienia z krajowym episkopatem, gdyż ten mógł pełnić najwyżej rolę pełnomocnika strony, jaką była Stolica Apostolska. Natomiast w przypadku innych wyznań brak było takiego podmiotu, który mógłby stanowić równorzędną państwu polskiemu stronę w bilateralnym układzie. Opierając się na tych argumentach, A. Halban konstatował: „Ja tu przywilejów nie widzę, a jeżeli ich się chce ktoś dopatrzeć, to nie są one przywilejami, lecz tylko konsekwencją istoty Kościoła"30.

W trakcie głosowań z 5 lutego 1921 r. wieńczących II plenarne czytanie projektu konstytucji Sejm Ustawodawczy przyjął zarówno art. 117 ust. 2 (zapowiedź zawarcia konkordatu), jak i art. 118 (ustawowy tryb ustalania stosunku państwa wobec pozostałych wyznań) w brzmieniu proponowanym przez Komisję Konstytucyjną, odrzucając jednocześnie poprawki zgłoszone do tych artykułów przez ZPPS i Koło Żydowskie. Wprowadzono zatem w redakcji projektu ustalonej w II czytaniu tę dwoistą i nierównorzędną drogę ustalania stosunków szczegółowych państwa z wyznaniami, która była tak mocno krytykowana w toku debaty przez posłów lewicy i mniejszości narodowych, widzących w niej pewne uprzywilejowanie Kościoła katolickiego ${ }^{31}$.

Spr. sten. SU, 187 pos. z 19 XI 1920 r., ł. 19-21.

31 Spr. sten. SU, 207 pos. z 5 II 1921 r., ł.18-19; Projekt ustawy konstytucyjnej w redakcji, przyjętej przez Sejm Ustawodawczy Rzeczypospolitej Polskiej w drugim czytaniu, druk SU nr 2442, s. [35]. 


\section{Sprawa konkordatu w trakcie III (finalnego) czytania projektu konstytucji}

Modyfikacje dokonane w projekcie konstytucji podczas końcowych prac Komisji Konstytucyjnej (trwały one w okresie od 10 lutego do 5 marca $1921 \mathrm{r}^{32}$ ), poprzedzających III czytanie na forum sejmu, objęły również kwestię prawnej formy regulacji stosunków między państwem a wyznaniami. W art. 114 ust. 2 zd. 2 (poprzednio art. 117 ust. 2 zd. 2) precyzyjniej zapowiedziano zawarcie konkordatu ze Stolicą Apostolską, określając go mianem „układu" zamiast wcześniej użytego słowa „porozumienie"33. Do artykułu tego posłowie PSL „Piast" zgłosili mniejszościową poprawkę, wedle której konkordat miałby podlegać ratyfikacji przez sejm. Zmianie uległa także forma ustalania szczegółowych stosunków państwa z pozostałymi wyznaniami. W nowym art. 115 ust. 2 (poprzednio art. 118) zapowiadano bowiem regulowanie tych kwestii w drodze ustawy, która miała być jednak uchwalona po porozumieniu się z prawnymi reprezentacjami wyznań, a nie jak wcześniej, jedynie po wysłuchaniu wniosków tychże reprezentacji. Modyfikacja ta sugerowała więc, że państwo zawrze dwustronne porozumienie z reprezentacją wyznaniową, usankcjonowane następnie w postaci ustawowej, a nie tylko zadecyduje jednostronnie, wysłuchawszy niewiążących opinii. Nadal jednak decydujące zdanie należało w tej kwestii do państwa jako silniejszego kontrahenta, dysponującego aparatem legislacyjnym, który uprawomocniał zawarte porozumienie. Ciągle uprzywilejowany był więc w pewnym stopniu Kościół katolicki, gdyż dla wejścia konkordatu w życie wedle projektu większości wystarczyło samo zawarcie układu przez strony ${ }^{34}$.

W trakcie III czytania projektu konstytucji (debata ta miała miejsce w dniach 8, 10-11 i 15 marca $1921 \mathrm{r}^{35}$ ), stanowiącego ogólne podsumowanie

Zob. Sprawozdanie Komisji Konstytucyjnej o Konstytucji Rzeczypospolitej Polskiej, druk SU nr 2561, s. 3.

33 Niekiedy w doktrynie pojawiały się głosy, że użyte wcześniej niezbyt ścisłe słowo „porozumienie" mogło w tym kontekście sugerować nie zawarcie jednej, całościowej umowy (konkordat), a konieczność każdorazowego ustalania w drodze umownej ze Stolicą Apostolską wszelkich modyfikacji w zakresie stosunku państwa do Kościoła. Zob. J. Sawicki, Studia nad położeniem prawnym mniejszości religijnych w państwie polskim, Warszawa 1937, s. 56; J. Wisłocki, Konkordat polski..., op. cit., s. 77.

Konstytucja Rzeczypospolitej Polskiej, w: Sprawozdanie Komisji Konstytucyjnej o Konstytucji Rzeczypospolitej Polskiej, druk SU nr 2561, s. 43; S. Krukowski, Geneza konstytucji..., op. cit., s. 292-293; Spr. sten. SU, 216 pos. z 8 III 1921 r., ł. 19-20. Por. druk SU nr 2442, s. [35].

S. Krukowski, Geneza konstytucji..., op. cit., s. 294. 
całokształtu spraw konstytucyjnych, do kwestii konkordatu wrócił jeszcze pokrótce K. Czapiński (ZPPS). Stwierdził on, że znajdująca się w art. 114 ust. 2 zd. 2 zapowiedź zawarcia konkordatu stanowi poważne ograniczenie suwerenności państwa polskiego, gdyż „nie wolno mu jednostronnie w obrębie własnej władzy i kompetencji uregulować swego stosunku do katolickiego wyznania, do katolickiej hierarchii". Dalej dodawał: „Musi tu państwo uklęknąć przed Rzymem i bez zgody owej naczelnej instancji rzymskiej nie wolno mu swego stosunku do kościoła uregulować. To jest owo uprzywilejowanie stanowiska katolickiego, bo w stosunku do ewangelików i innych wyznań (art. 115 i 116) wolno Państwu precyzować swoje stanowisko, wolno decydować tak, jak ono chce, żeby ustrój owego wyznania wyglądał"36. K. Czapiński podkreślał więc nierówne jego zdaniem traktowanie wyznań, przejawiające się również w dwustronnym, szczególnym charakterze konkordatu. Sprzeciwiał się stanowczo dzieleniu społeczeństwa na wyznawców religii uprzywilejowanej (katolicy) i na pozostałych, "drugorzędnych obywateli". O konkordacie wypowiedział się jeszcze referent generalny projektu konstytucji, a zarazem przewodniczący Komisji Konstytucyjnej, Edward Dubanowicz, zasiadający w ławach centrowego Narodowego Zjednoczenia Ludowego. Odniósł się on do jednej z poprawek zgłoszonych do tego artykułu przez klub PSL „Piast". Ludowcy wnosili w niej o dodanie wymogu ratyfikacji przez sejm konkordatu zawartego ze Stolicą Apostolską ${ }^{37}$. Sprawozdawca uznał gwarantowanie tej kwestii aż na szczeblu konstytucji za niepotrzebne ${ }^{38}$.

Podczas decydującego głosowania z 16 marca 1921 r. nad art. 114 ust. 2 zd. 2 projektu konstytucji, zawierającym zapowiedź zawarcia przez państwo konkordatu, doszło do uchwalenia przepisu w brzmieniu komisyjnym, wzbogaconym jednak o przyjętą wówczas poprawkę PSL "Piast" wprowadzającą wymóg ratyfikowania tejże umowy ze Stolicą Apostolską przez sejm (za głosowało 190, a przeciw - 172 posłów). Z kolei bez żadnych zmian względem redakcji proponowanej przez Komisję przyjęto art. 115, którego ust. 2 wprowadzał zasadę ustalenia stosunku państwa do innych wyznań w drodze ustawowej, po porozumieniu się z ich prawnymi reprezentacjami ${ }^{39}$.

Zob. druk SU nr 2561, s. 43.

Spr. sten. SU, 219 pos. z 15 III 1921 r., ł. 29-30.

Spr. sten. SU, 220 pos. z 16 III 1921 r., ł. 20-21; S. Krukowski, Geneza konstytucji..., op. cit., s. 302 .

Paweł Magiera, Spór o zawarcie konkordatu ze Stolica Apostolska... 


\section{Uwagi końcowe}

Podsumowując, w Konstytucji marcowej znalazł swój prawny wyraz model niejako kompromisowy względem przepisów z II czytania, który z jednej strony opierał się na akceptacji organizacyjnej odmienności Kościoła katolickiego (co wiązało się w konsekwencji z wprowadzeniem zapowiedzi zawarcia konkordatu ze Stolicą Apostolską), natomiast z drugiej strony przewidywał konieczność wypracowania przez państwo sankcjonowanego ustawowo bilateralnego porozumienia z pozostałymi związkami wyznaniowymi. Zastrzec jednak należy, że nie likwidowało to w pełni nierównorzędności obu stron takiego porozumienia, gdyż niewątpliwie silniejszą i decydującą pozycję w takim układzie miało państwo, którego aparat ustawodawczy finalnie utrwalał wypracowane porozumienie $\mathrm{w}$ formie ustawy. Mimo to złagodzono w pewnej mierze problem nierównoprawnej drogi określania szczegółowych relacji państwa do Kościoła katolickiego i do pozostałych związków religijnych, w ten sposób wychodząc częściowo naprzeciw głosom krytycznym wyrażonym w toku debaty konstytucyjnej przez posłów mniejszości żydowskiej oraz sejmowej lewicy.

Warto zauważyć, iż w toku debaty sejmowej w konstytuancie zaznaczyła się wyraźnie różnica w postrzeganiu konkordatu. Dla posłów lewicowych oraz przedstawicieli mniejszości religijnych konkordat stanowił bowiem przywilej dla Kościoła katolickiego gwarantujący mu szczególną pozycję w relacjach z państwem. Oceny takiej dokonywano zwłaszcza przez pryzmat porównania z regulacją zaproponowaną w stosunku do pozostałych wyznań, podkreślając tu jednostronność decyzji państwa, w przeciwieństwie do bilateralnej umowy dwóch równorzędnych podmiotów, jaką miał być konkordat. Z kolei posłowie ugrupowań prawicowych i prawego centrum negowali rzekomy walor uprzywilejowujący konkordatu. Uznawali go za jedyną możliwą formę prawną regulacji stosunków Kościoła katolickiego z państwem, będącą bezpośrednią konsekwencją wyjątkowej, właściwej tylko dla niego struktury organizacyjnej tego Kościoła, który posiadał scentralizowany ośrodek władzy - Stolicę Apostolską (papiestwo), funkcjonujący jednocześnie jako pełnoprawny podmiot prawa międzynarodowego. W tym ujęciu konkordat nie był więc żadnym przywilejem, a jedynie koniecznością, oczywistym i nieuniknionym rezultatem odmienności strukturalnej Kościoła katolickiego na tle innych związków wyznaniowych.

Wspomniana różnica w rozumieniu samej umowy oraz zasady konkordatu była w istocie wyrazem sięgających o wiele szerzej różnic 
światopoglądowych, które z ogromną mocą zaznaczały się właśnie w toku prac ustrojowych konstytuanty w pierwszych latach II Rzeczypospolitej. Choć przesądzono wówczas w Konstytucji marcowej samą kwestię zawarcia konkordatu (poprzez umieszczenie stosownej zapowiedzi w art. 114 ustawy zasadniczej), to batalia o jego szczegółowy kształt miała się dopiero rozpocząć. Żmudne prace i zabiegi dyplomatyczne nad obliczem tej umowy przeciągnęły się aż do 1925 r. i przyniosły wiele kontrowersji. Dopiero w parlamencie I kadencji doszło do najsłynniejszej debaty o konkordacie, której przedmiotem było ratyfikowanie przez izby umowy podpisanej 10 lutego 1925 r. Ta o wiele bardziej znana, gorąca debata (zwłaszcza w sejmie w marcu 1925 r.) nad ratyfikacją konkordatu stała się ostatnim akordem tej kontrowersyjnej dla wielu sprawy ${ }^{40}$. Jak jednak próbowano przypomnieć na gruncie niniejszego opracowania, pierwszym akcentem parlamentarnym tego zagadnienia była właśnie debata tocząca się już w latach 1919-1921 w Sejmie Ustawodawczym, prowadzona w ramach prac konstytucyjnych odrodzonej Rzeczypospolitej. 


\section{Bibliografia}

\section{Źródła}

Druki Sejmu Ustawodawczego Rzeczypospolitej Polskiej (z lat 1919-1921), dostępne online, https://bs.sejm.gov.pl/F?func=scan\&scan_

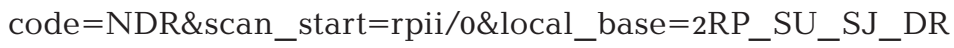
(30.09.2018).

Dziennik Ustaw Rzeczypospolitej Polskiej (1921).

Sprawozdania stenograficzne z posiedzeń Sejmu Ustawodawczego Rzeczypospolitej Polskiej (z lat 1919-1921), dostępne online, https://bs.sejm.gov.pl/F?func =scan\&scan_code=NST\&scan_ start=rpii/o\&local_base=2RP_SU_SJ_ST (30.09.2018).

\section{Opracowania}

Dębiński J., O konkordacie polskim z 1925 roku, "Saeculum Christianum", t. 14, nr 1 (2007), s. 169-189.

Dyjakowska M., Privilegium odiosum. O znaczeniu kontekstu w przekładzie terminologii prawniczej, "Roczniki Humanistyczne”, t. 61 , nr 8 (2013), s. $149-161$.

Krasowski K., Konkordat polski z 1925 roku. Geneza - postanowieniawykonanie, "Politeja", t. 29, nr 29 (2014), s. 283-313.

Krasowski K., Między Warszawa a Watykanem. Episkopat Polski wobec rządu i Stolicy Apostolskiej 1918-1939, w: Szkice z dziejów papiestwa, t. 1, red. I. Koberdowa, J. Tazbir, Warszawa 1989, s. 269-405.

Krukowski S., Geneza konstytucji z 17 marca 1921 r., Warszawa 1977.

Michałowski S., Religia i Kościół rzymskokatolicki w myśli politycznej Polskiej Partii Socjalistycznej 1918-1939, w: Religia i Kościół rzymskokatolicki w polskiej myśli politycznej 1919-1993, red. J. Jachymek, Lublin 1995, s. 135-150.

Rudnicki Sz., Żydzi w parlamencie II Rzeczypospolitej, Warszawa 2004. Rzepecki T., Sejm Rzeczypospolitej Polskiej 1919 roku, Poznań 1920. Sawicki J., Studia nad położeniem prawnym mniejszości religijnych w państwie polskim, Warszawa 1937. 
Wilk S., Episkopat Kościoła katolickiego w Polsce w latach 1918-1939,

Warszawa 1992.

Wisłocki J., Konkordat polski z 1925 roku. Zagadnienia prawno-polityczne, Poznań 1977.

Wójcik W., Konkordat polski z 1925 roku. Próba oceny, w: Kościół

w II Rzeczypospolitej, red. Z. Zieliński, S. Wilk, Lublin 1980, s. 15-34.

Wyczawski H.E., Kościół w odrodzonym państwie polskim (1918-1939),

w: Historia Kościoła w Polsce, t. II, cz. 2, red. B. Kumor,

Z. Obertyński, Poznań-Warszawa 1979, s. 5-92.

Paweł Magiera, Spór o zawarcie konkordatu ze Stolica Apostolska... 


\section{Abstrakt}

\section{Paweł Magiera}

Spór o zawarcie konkordatu ze Stolica Apostolska w debacie konstytucyjnej Sejmu Ustawodawczego z lat 1919-1921

\section{Słowa kluczowe:}

II Rzeczpospolita, konkordat, Sejm Ustawodawczy 1919-1922, debata konstytucyjna
Artykuł przedstawia w sposób kompleksowy mało dotychczas znaną debatę nad kwestią zawarcia przez II Rzeczpospolitą konkordatu ze Stolicą Apostolską, która toczyła się w Sejmie Ustawodawczym w latach 1919-1921, w ramach parlamentarnych prac nad konstytucją odrodzonego państwa. W odróżnieniu od szeroko dotąd omawianej dyskusji parlamentarnej z 1925 r. nad ratyfikacją podpisanego już konkordatu, przeprowadzonej w Sejmie I kadencji, ta pierwsza debata z okresu prac konstytuanty dotyczyła jedynie umocowania samej zapowiedzi zawarcia konkordatu w treści przyszłej konstytucji, była niejako debatą "na przedpolu", która przesądzić miała o formie prawnej przyszłego ułożenia szczegółowych stosunków przez państwo z poszczególnymi związkami wyznaniowymi, a zwłaszcza z Kościołem katolickim. Tytułowe zagadnienie przedstawiono z zastosowaniem kryterium chronologicznego, oddając w ten sposób zasadniczy porządek prowadzonych w sejmie prac konstytucyjnych. Opracowanie przygotowano głównie w oparciu o źródła parlamentarne, w postaci stenogramów i druków Sejmu Ustawodawczego, które pozwoliły odtworzyć dyskusję poselską nad kwestią konkordatu, toczącą się wówczas na sali sejmowej.

Folia Historica Cracoviensia, t. 24, z. 2 (2018) 


\section{Abstract}

\section{Paweł Magiera}

The Dispute over the Signing of the Concordat between the Second Polish Republic and the Holy See in the Constitutional Debate of the Legislative Sejm in Years 1919-1921

The article shows comprehensively a little-known subject of the first debate over the signing of the concordat between the Second Polish Republic and the Holy See that took place during the constitutional debate of the Legislative Sejm in years 1919-1921. In contrast to the parliamentary dispute in 1925 over the final ratification of the concordat, which was widely presented in the contemporary literature, the first debate in the Legislative Sejm was only a prelude and focused on establishing the sole principle of the concordat in the text of future constitution. According to it, this first debate determined only the legal way in which detailed relations between the Catholic Church and the state should be established in the future. The subject of the article was presented in chronological order, which corresponds with the sequence of constitutional efforts in the parliament. The article is based mainly on the historical sources in the form of stenographic records and documents of the Legislative Sejm (1919-1922). Its analysis makes it possible to recreate the first parliamentary debate over the principle of concordat in future constitution.
Keywords: the Second Polish Republic, concordat, the Legislative Sejm 1919-1922, constitutional debate 